\title{
13
}

\section{Contract preferences and psychological determinants of participation in agri-environment schemes}

\author{
Romy Greiner
}

\section{Key lessons}

- Agri-environment schemes offer positive financial incentives to farmers, and are favoured by farmers over other policy approaches, but this does not translate into unconditional participation. To maximise participation, agri-environment scheme design needs to consider farmer preferences for contract features, motivations, and attitudes.

- In general, farmers are more likely to sign up to agri-environment scheme contracts that allow some form of agricultural production on the contract area, offer a higher per hectare payment, are shorter, allow flexibility, and are externally monitored.

- Preferences are context specific and there is significant variation in preferences among farmers, meaning that a suite of agri-environment scheme contract options works best to maximise participation. But contract choice must not compromise the intended conservation result. 
- Agri-environment schemes need to be supported by complementary measures, such as information and extension, to shape attitudes and ensure that agri-environment scheme design, implementation, and administration do not jeopardise existing altruism and intrinsic motivation for conservation among farmers.

- Biodiversity conservation on private land, funded by voluntary contractual arrangements, is likely to be an expensive way to do conservation. From the perspective of efficiency and permanency of investment, inclusion of land into the formal conservation estate is preferable. However, agri-environment schemes can play a vital role of securing strategically important areas into a multi-tenure conservation system in the short- to medium-term.

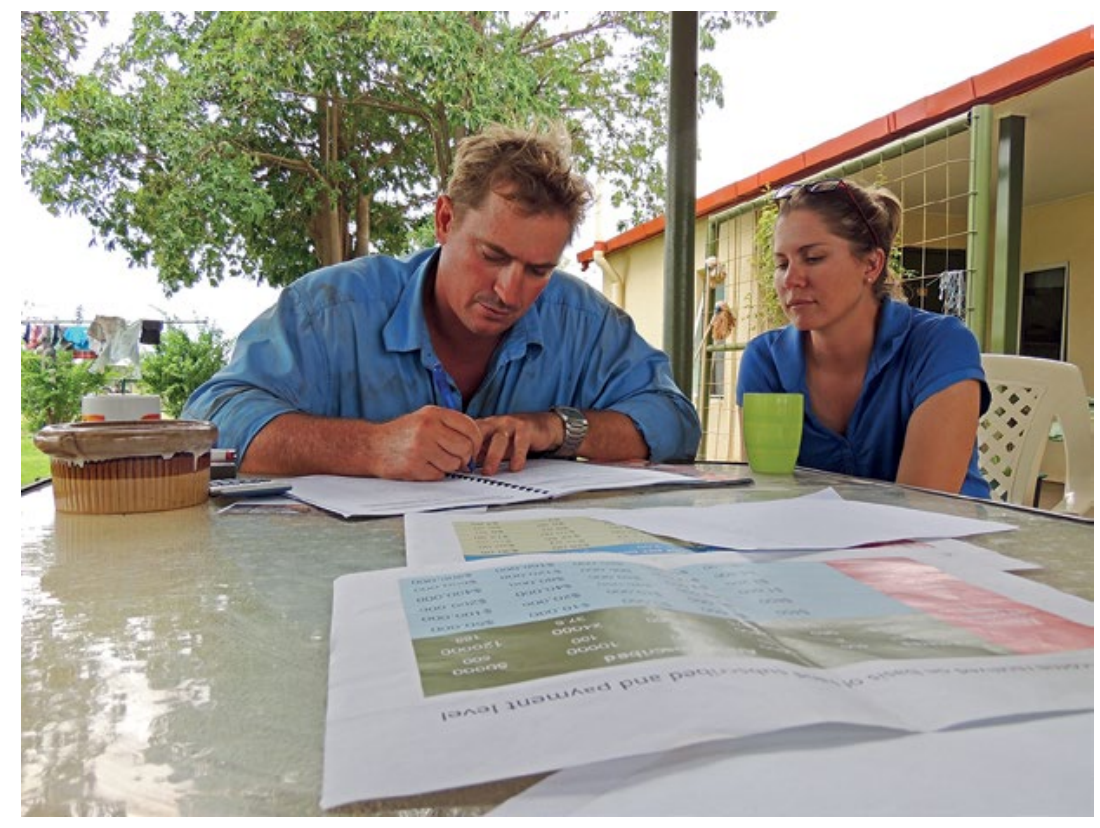

Figure 13.1: Conducting research on pastoralists' participation in contractual biodiversity conservation at Hayfield Station in the Northern Territory.

Source: Photo by Romy Greiner.

Paying farmers for environmental services is a novel concept in the vast landscapes of northern Australia. These landscapes remain sparingly used and the tropical savannas vegetation has been largely retained (Greiner et al. 2009a). But degradation is occurring, and pressures 
for agricultural development and intensification are mounting. The opportunity still exists to prevent the scale of environmental decline and species extinctions that has been experienced in other parts of Australia. Could agri-environment schemes be an effective policy instrument to safeguard northern Australia's biodiversity, and, if so, what should an effective agri-environment scheme look like?

Europe has 30 years' experience with conservation programs, which provide incentives directly to farmers to protect and manage land for biodiversity. A recent review of these biodiversity agri-environment schemes has shown that they can be effective for conserving wildlife on farmland, but that agri-environmental schemes need to be carefully designed to achieve their goals (Batáry et al. 2015). Schemes need to be feasible across large landscapes and incentivise landholder participation.

An obvious aspect of agri-environmental scheme design is deciding on the level of incentive to pay to participating landholders. Microeconomic theory of profit maximisation might suggest that landholders will consider participating in a scheme if they do not incur a net loss of income. Assuming that a switch to conservation-focused land management causes a loss of income in most circumstances and can result in additional costs, the financial incentive has to at least compensate these imposts. However, a singular focus on the financial dimension is misguided, because adoption and participation decisions by farmers are influenced by consideration of various aspects of the innovation (Pannell et al. 2006). In the context of agri-environment schemes this means that, in addition to its immediate financial dimension, other contract attributes are also important, as are social and psychological factors (Greiner et al. 2009b).

As the theory of planned behaviour explains, psychological factors such as motivations and attitudes can be important predictors of behaviour (Ajzen 1991), including adoption of innovation and program participation. Knowledge of which factors influence participation, and how, can help with the design and implementation of agri-environment schemes so as to maximise farmer participation, improve scheme effectiveness, and maximise efficiency of investment. 
This chapter summarises relevant knowledge and offers illustrations based on a survey of 104 farmers in northern Australia, as part of the Australian Government's National Environmental Research Program Northern Australia Hub. Face-to-face interviews were conducted with pastoral land owners and land managers, mostly on their properties. Respondents represent approximately 15 per cent of farmers in the rangelands of the tropical savannas and manage a combined area of over 250,000 $\mathrm{km}^{2}$ of land. Methodological specifications and detailed results can be gleaned from Greiner (2014a, 2015) and Greiner et al. (2014).

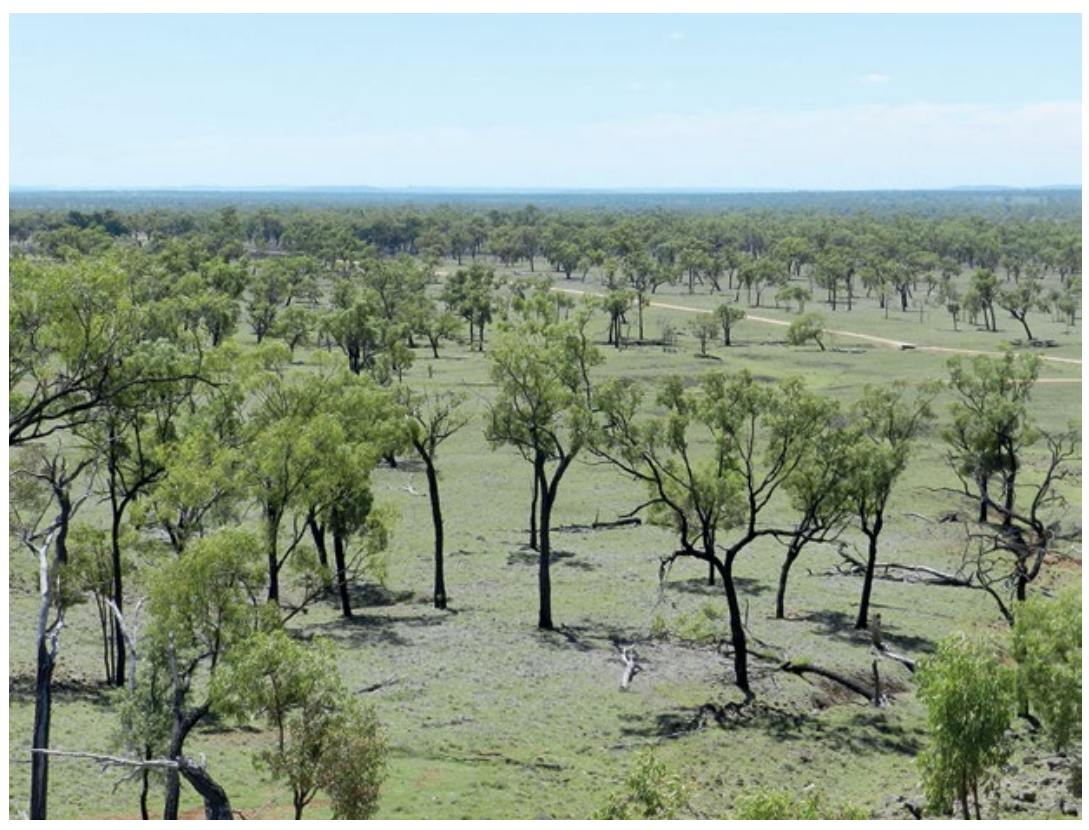

Figure 13.2: The Einasleigh Uplands are one landscape within northern Australian tropical savannas.

Source: Photo by Romy Greiner.

\section{Farmers have diverse preferences for contract attributes}

Agri-environment schemes are principally implemented using contracts between purchasers of conservation services, typically governments, and farmers as providers of various conservation services. In essence, 
an agri-environment scheme constitutes a payment for environmental services (Greiner et al. 2009a). Contract attributes as a minimum entail the conservation actions that farmers have to undertake, the level of stewardship payment they receive in return $(\$ / \mathrm{ha})$, and duration of the agreement (years). They also tend to stipulate arrangements about monitoring and administration, and possible flexibility provisions.

The payment levels offered in the choice experiment were guided by long-term estimates of farm cash income in the tropical savannas and industry consultations. Across the tropical savannas, the average annual cash income is approximately $\$ 3$ per hectare (DAFF 2014, 2013 equivalent values). However, income is highly variable, both temporally and spatially: the coefficient of variation between 1990-2013 is close to 100 per cent, and in good seasons cash income can be four times the average income, while in bad seasons cash income is negative. Across the tropical savannas there are vast areas of marginal land with zero productivity while some pockets of fertile land average 10 times the landscape average cash income.

A body of literature is dedicated to exploring how farmers trade-off contract attributes against each other and the per hectare payment (e.g. Garrod et al. 2012; Burton and Schwarz 2013; Espinosa-Goded et al. 2010; Broch and Vedel 2012). The literature shows that, in general, farmers prefer higher payments, shorter contracts, more flexibility, less accountability, and less paperwork. Preferences and trade-offs are context specific, meaning they are dependent on the geographical setting, type of agricultural sector, and the conservation goal to be achieved.

Observed and stated preference techniques can be used to quantify farmers' preferences and how they trade off between contract attributes, and to explain how each attribute affects the likely participation by farmers in the scheme. Preferences indicate the monetary value that farmers attach to contract attributes. If, for example, a farmer's preference is for a short contract and the funder wants to offer a long contract, then the funder will most likely need to offer a higher per-hectare stewardship payment to secure the farmer's participation.

The research with northern Australian farmers used a stated preference technique — choice experiment - to explore participation in hypothetical biodiversity conservation contracts 
(Greiner et al. 2014). Biodiversity in this context was defined as native flora and fauna, and the ecosystems that support them. Analysis of the choice experimental data confirmed the aforementioned generic findings in the literature regarding preferences for contract features and provided context specific preference estimates (Greiner 2015). For example, across the industry, graziers were asking for a $\$ 0.40$ increase in annual per hectare payment (value in 2013 equivalent) for an additional year of contract duration. In terms of the conservation requirement, across the industry, graziers required an extra $\$ 11.08$ per hectare a year (95 per cent confidence interval: $\$ 7.45-\$ 14.47$ ) as a premium for participation in contracts for the complete removal of cattle from the contract area, compared to contract options that required the exclusion of cattle for only a short period of time each year (such as when the biodiversity was most susceptible to grazing impact). This would suggest that, across the industry, landholders are benchmarking opportunity costs against income in favourable years rather than long-term average conditions - they are hedging their bets with participation in agri-environment schemes.

The results of that choice experiment also illustrated the significant variation in preferences for all contract attributes (Greiner 2015). For example, across the industry, some farmers preferred that monitoring of contract compliance be undertaken by external providers, and others preferred to undertake the monitoring themselves (with occasional spot checks). Some farmers charged a very high premium for total exclusion of cattle, while others were prepared to accept this option more cheaply, all else being equal - but still at a premium above opportunity cost. Understanding the diversity of preferences for contract attributes - even within a seemingly homogenous farming sector such as the northern beef industry helps investors to gauge the likely responses by farmers in a region or in an industry to certain contract features. This information consequently enables agri-environment scheme design to be tailored - contractually and administratively - so as to ensure fit for purpose and program efficiency. 


\section{Making money is important but other goals may be more important to some}

Age and education are the personal characteristics of farmers most often associated with participation in agri-environment schemes (see Chapter 10). However, in the research with northern Australian farmers, neither of these characteristics was found to have a significant influence (Greiner 2015). Psychological constructs, such as attitudes and motivations, seem to be more relevant to behaviour. Both have previously been found to be antecedents of conservation behaviour of northern Australian farmers (Greiner and Gregg 2011). Empirical research with farmers elsewhere has similarly established the importance of motivations (see Chapter 12). To test this theory in the context of agri-environment scheme participation, the survey included separate five-point Likert scales to derive measures of motivation and attitudes towards biodiversity (Greiner 2014a).

The research found that the five most highly rated goals (based on mean value of motivation items) did not include financial items but were to: 'look after cattle', 'get satisfaction from living and working on the land', 'pass on land in good condition', 'enjoy life and work on the property', and 'look after the natural assets of the property' (see Table 13.1). Survey results supported the idea that farmers in northern Australia have a high intrinsic stewardship motivation for safeguarding their cattle, land, and biodiversity assets, and that this is fundamentally linked to the pursuit of pastoralism as a chosen lifestyle (Greiner and Gregg 2011).

Principal component factor analysis was used to group the goals into broad themes, or factors, which represented three different types of motivations: 'stewardship and lifestyle motivation', 'social motivation', and 'economic/financial motivation'. Respondents who tended to have high ratings for stewardship and lifestyle motivation were driven by a custodianship ethic ('look after the natural assets', 'look after cattle') combined with enjoyment of their work and lifestyle. Farmers who tended to score highly on economic/financial motivation were driven by wanting to generate profit, income, and assets. Farmers who scored highly on social motivation tended to be more strongly driven by family considerations and making a contribution to global food production. 
The motivational profile is consistent with the literature (Maybery et al. 2005) and, importantly, supports the motivation factor structure of pastoralists proposed by Greiner et al. (2009b). That research had demonstrated a positive correlation between graziers' level of stewardship and lifestyle motivation and the adoption of best practice grazing land management, including the spelling of riparian areas and early de-stocking of the property when drought conditions were emerging. The recent choice experiment similarly found a significant positive influence of intrinsic interest in biodiversity - defined as the native animals and plants - and likelihood of participation in agri-environment schemes (Greiner 2015).

Table 13.1: What motivates pastoralists and graziers: Mean rating scores and factor loadings from a survey of northern Australian farmers $(n=104)$.

\begin{tabular}{|c|c|c|c|c|}
\hline \multirow[t]{2}{*}{ Motivation items ${ }^{1}$} & \multirow{2}{*}{$\begin{array}{l}\text { Mean } \\
\text { rating } \\
\text { score }^{2}\end{array}$} & \multicolumn{3}{|c|}{ Motivation factors ${ }^{3}$} \\
\hline & & $\begin{array}{l}\text { Stewardship } \\
\text { and lifestyle } \\
\text { motivation }\end{array}$ & $\begin{array}{c}\text { Social } \\
\text { motivation }\end{array}$ & $\begin{array}{l}\text { Economic } \\
\text { and } \\
\text { financial } \\
\text { motivation }\end{array}$ \\
\hline $\begin{array}{l}\text { Look after the natural assets of the } \\
\text { property }\end{array}$ & 4.5 & 0.8 & & \\
\hline Pass on land in good condition & 4.6 & 0.8 & & \\
\hline $\begin{array}{l}\text { Safeguard the property's natural } \\
\text { assets }\end{array}$ & 4.4 & 0.7 & & \\
\hline Enjoy life and work on the property & 4.6 & 0.7 & & \\
\hline Improve resource/land condition & 4.3 & 0.7 & & \\
\hline Protect the environment & 4.3 & 0.7 & & \\
\hline Look after cattle & 4.6 & 0.6 & & \\
\hline $\begin{array}{l}\text { Get satisfaction from living and } \\
\text { working on the land }\end{array}$ & 4.6 & 0.6 & & \\
\hline Produce high-quality cattle & 4.4 & 0.6 & & \\
\hline Raise family on a grazing property & 3.7 & & 0.8 & \\
\hline Retire on the farm & 2.5 & & 0.6 & \\
\hline Ride horses/motorbikes/helicopters & 3.1 & & 0.6 & \\
\hline $\begin{array}{l}\text { Put children through school/ } \\
\text { university }\end{array}$ & 4.0 & & 0.6 & \\
\hline Step in ancestors' footsteps & 2.3 & & 0.6 & \\
\hline $\begin{array}{l}\text { Produce beef to help feed the world } \\
\text { population }\end{array}$ & 3.9 & & 0.5 & \\
\hline
\end{tabular}




\begin{tabular}{|c|c|c|c|c|}
\hline \multirow[t]{2}{*}{ Motivation items ${ }^{1}$} & \multirow{2}{*}{$\begin{array}{l}\text { Mean } \\
\text { rating } \\
\text { score }^{2}\end{array}$} & \multicolumn{3}{|c|}{ Motivation factors ${ }^{3}$} \\
\hline & & $\begin{array}{c}\text { Stewardship } \\
\text { and lifestyle } \\
\text { motivation }\end{array}$ & $\begin{array}{c}\text { Social } \\
\text { motivation }\end{array}$ & $\begin{array}{l}\text { Economic } \\
\text { and } \\
\text { financial } \\
\text { motivation }\end{array}$ \\
\hline Earn a high income & 3.1 & & & 0.7 \\
\hline Maximise company profit & 4.0 & & & 0.7 \\
\hline $\begin{array}{l}\text { Maximise cattle production from } \\
\text { the land }\end{array}$ & 4.0 & & & 0.7 \\
\hline $\begin{array}{l}\text { Avoid years with very little or } \\
\text { negative income }\end{array}$ & 3.8 & & & 0.6 \\
\hline Build up land, wealth and assets & 3.9 & & & 0.5 \\
\hline Be among the best in the industry & 3.5 & & & 0.5 \\
\hline Run a profitable business & 4.4 & & & 0.5 \\
\hline Eigenvalue & & 6.0 & 2.5 & 2.2 \\
\hline Cumulative (Eigenvalue) & & 6.0 & 8.6 & 10.7 \\
\hline$\%$ Total (variance) & & 27.4 & 11.5 & 9.9 \\
\hline Cumulative (\%) & & 27.4 & 38.9 & 48.8 \\
\hline
\end{tabular}

${ }^{1}$ Items in the table are sorted by factor association and loading value.

'Survey question: 'When you think about being a land owner/manager and pastoralist, how important are the following motivations to you?' A five-point response scale with 1='not at all important' to 5='extremely important'.

${ }^{3}$ Factor analysis conducted in Statistica 12, principal component extraction of factors, varimax orthogonal rotation, pairwise deletion of missing values, deletion of items with factor loadings $<0.5$.

Table 13.2: Attitudes of graziers and pastoralists towards biodiversity: Agreement with attitudinal statements and attitude factor scores from a survey of northern Australian farmers $(n=104)$.

\begin{tabular}{|l|c|c|c|c|}
\hline Attitudinal statements $^{1}$ & Mean $^{\text {score }}{ }^{2}$ & \multicolumn{3}{|c|}{ Biodiversity attitudes $^{3}$} \\
\cline { 3 - 5 } & & $\begin{array}{c}\text { Stewardship } \\
\text { ethic }\end{array}$ & $\begin{array}{c}\text { Causes of/ } \\
\text { solutions to } \\
\text { biodiversity } \\
\text { decline }\end{array}$ & $\begin{array}{c}\text { Biodiversity } \\
\text { on own } \\
\text { property }\end{array}$ \\
\hline $\begin{array}{l}\text { As a landowner/land manager, } \\
\text { I have an obligation to look after } \\
\text { the native biodiversity and other } \\
\text { natural assets on the property }\end{array}$ & 4.5 & 0.8 & & \\
\hline $\begin{array}{l}\text { Caring for biodiversity is } \\
\text { important to me personally }\end{array}$ & 4.2 & 0.7 & & \\
\hline
\end{tabular}




\begin{tabular}{|c|c|c|c|c|}
\hline \multirow[t]{2}{*}{ Attitudinal statements ${ }^{1}$} & \multirow{2}{*}{$\begin{array}{l}\text { Mean } \\
\text { score }^{2}\end{array}$} & \multicolumn{3}{|c|}{ Biodiversity attitudes $^{3}$} \\
\hline & & $\begin{array}{c}\text { Stewardship } \\
\text { ethic }\end{array}$ & $\begin{array}{l}\text { Causes of/ } \\
\text { solutions to } \\
\text { biodiversity } \\
\text { decline }\end{array}$ & $\begin{array}{l}\text { Biodiversity } \\
\text { on own } \\
\text { property }\end{array}$ \\
\hline $\begin{array}{l}\text { I take pleasure from seeing } \\
\text { native biodiversity around }\end{array}$ & 4.3 & 0.7 & & \\
\hline $\begin{array}{l}\text { Every pastoralist has a moral } \\
\text { responsibility to look after the } \\
\text { biodiversity and other natural } \\
\text { assets on his/her land }\end{array}$ & 4.3 & 0.6 & & \\
\hline $\begin{array}{l}\text { Abundance of certain native } \\
\text { animals is an indicator of the } \\
\text { health of the country }\end{array}$ & 4.1 & 0.6 & & \\
\hline $\begin{array}{l}\text { Grazing plays a minor role in } \\
\text { biodiversity decline compared } \\
\text { to other pressures }\end{array}$ & 3.5 & & 0.8 & \\
\hline $\begin{array}{l}\text { Statutory duty of care is } \\
\text { sufficient to protect biodiversity }\end{array}$ & 2.9 & & 0.7 & \\
\hline $\begin{array}{l}\text { Feral animals and plants pose } \\
\text { a greater threat to native } \\
\text { biodiversity than grazing }\end{array}$ & 4.1 & & 0.7 & \\
\hline $\begin{array}{l}\text { Current national parks } \\
\text { are sufficient to safeguard } \\
\text { biodiversity of the savannas }\end{array}$ & 2.9 & & 0.6 & \\
\hline $\begin{array}{l}\text { I have noticed a decline of } \\
\text { native animals and plants on } \\
\text { my property }\end{array}$ & 1.9 & & & 0.7 \\
\hline $\begin{array}{l}\text { Protecting endangered species } \\
\text { on my property is easy }\end{array}$ & 2.8 & & & -0.7 \\
\hline $\begin{array}{l}\text { It is relatively easy to safeguard } \\
\text { native biodiversity on my } \\
\text { property }\end{array}$ & 3.4 & & & -0.7 \\
\hline Eigenvalue & & 2.7 & 2.0 & 1.4 \\
\hline Cumulative (Eigenvalue) & & 2.7 & 4.8 & 6.2 \\
\hline \% Total (variance) & & 19.5 & 14.5 & 10.3 \\
\hline Cumulative (\%) & & 19.5 & 34.0 & 44.2 \\
\hline
\end{tabular}

${ }^{1}$ Statements in the table are sorted by factor association and loading values.

'Survey question: 'How strongly do you agree or disagree with the following statements?' five-point response scale with $1=$ ='strongly disagree' to $5=$ ='strongly agree'.

${ }^{3}$ Factor analysis conducted in Statistica 12, principal component extraction of factors, varimax orthogonal rotation, pairwise deletion of missing values, deletion of items with factor loadings $<0.5$. 


\section{How farmers relate to biodiversity and what they think about agri-environment schemes influences likely participation in agri-environment schemes}

The survey explored attitudes towards biodiversity and policy tools, including agri-environment schemes. Biodiversity attitudes were derived using factor analysis from the level of agreement with a Likert scale containing biodiversity related statements. The three-factor model provided a parsimonious construct of how farmers related to and thought about biodiversity (Table 13.2).

The factors captured the level of stewardship ethic, what farmers believed to be the causes of and solutions to biodiversity decline on pastoral land, and the extent to which they thought they could influence biodiversity on their properties. Farmers who scored highly on the 'stewardship ethic' factor attributed higher intrinsic value to biodiversity and believed landholders had a duty of care towards biodiversity. Farmers who scored highly on the 'causes of decline' factor tended to believe that biodiversity decline was mainly caused by factors other than grazing and that the formal conservation estate was sufficient to safeguard biodiversity. Farmers who scored highly on the 'biodiversity on own property' factor tended to notice a decline of biodiversity on their properties and did not think that safeguarding of biodiversity was a trivial task.

When these factors were included into the choice models, 'stewardship ethic' was shown to significantly and positively influence likely participation in agri-environment schemes (Greiner 2015). The level of 'stewardship ethic' as an attitude was significantly positively correlated with 'stewardship and lifestyle motivation' $(\mathrm{p}<0.001)$. Interpreted through the lens of Chapter 14, this can be interpreted as meaning farmers with higher stewardship ethic derive nonmonetary private benefits from participation in agri-environment schemes, which reduces the financial incentive required. Accounting for these kinds of benefits when planning conservation can increase agri-environment schemes efficiency (for example, more biodiversity conservation for the same amount of program expenditure).

This research measured farmers' attitudes towards agri-environment schemes in terms of perceived effectiveness and found that, in general, farmers rated agri-environment schemes similarly favourably as 
income tax incentives and as more effective in incentivising more onfarm conservation than property planning, research, persuasion, and recognition measures (Table 13.3). Farmers who rated agri-environment schemes more favourably were found to be more likely to participate in contractual biodiversity conservation (Greiner 2015).

\section{Table 13.3: Preferences for policy instruments and other measures: Perceived effectiveness based on a survey of northern Australian farmers $(n=104)$.}

\begin{tabular}{|l|c|c|}
\hline Policy instruments and other items & $\begin{array}{c}\text { Mean } \\
\text { score }^{2}\end{array}$ & $\begin{array}{c}\text { Standard } \\
\text { deviation }\end{array}$ \\
\hline $\begin{array}{l}\text { Government investment in safeguarding/expanding overseas } \\
\text { cattle markets }\end{array}$ & 4.1 & 1.1 \\
\hline Income tax incentives & 3.8 & 1.0 \\
\hline $\begin{array}{l}\text { Financial incentives schemes (payments for ecosystem } \\
\text { services) such as the ones explored in this research }\end{array}$ & 3.8 & 1.1 \\
\hline Property management planning & 3.5 & 1.1 \\
\hline $\begin{array}{l}\text { Increased public acknowledgement of environmental } \\
\text { achievements by graziers }\end{array}$ & 3.4 & 1.2 \\
\hline More research into animals and grazing systems & 3.4 & 1.1 \\
\hline Courses in grazing systems/grazing land management & 3.3 & 1.2 \\
\hline More extension and consulting services offered on-farm & 3.2 & 1.1 \\
\hline Debt-for-conservation swaps & 3.1 & 1.3 \\
\hline Environmental management plans/systems & 3.1 & 1.0 \\
\hline $\begin{array}{l}\text { Industry organisations promoting the benefits of farm } \\
\text { enterprise diversification }\end{array}$ & 3.1 & 1.2 \\
\hline Voluntary (industry and regional) grazing code of practice & 2.8 & 1.1 \\
\hline $\begin{array}{l}\text { Increased peer recognition of grazier achievements } \\
\text { (e.g. awards) }\end{array}$ & 2.5 & 1.1 \\
\hline $\begin{array}{l}\text { Community involvement (volunteers, schools) in on-ground } \\
\text { works }\end{array}$ & 2.4 & 1.2 \\
\hline
\end{tabular}

${ }^{1}$ Items in the table sorted by mean effectiveness value.

${ }^{2}$ Survey question: 'How effective would the following measures be in helping you to undertake (more) conservation activities on your operation?'. A five-point response scale with $1=$ 'not at all effective' to $5=$ 'extremely effective'. 


\section{What this means for agri-environment scheme design}

The empirical research summarised in this chapter suggests that agri-environment schemes are well liked by farmers and that participation in agri-environment schemes is readily considered once such programs are available to farmers. Participation decisions have been found to be subject to a number of factors. In addition to farm economic considerations about associated benefits and costs, a farmer's decision to participate in an agri-environment scheme at a certain incentive level is likely to be influenced by his or her like or dislike of contractual features, the trade-offs between contractual features, the reasons that drive him or her to be a farmer, and how he or she relates to the natural environment - in this case, biodiversity.

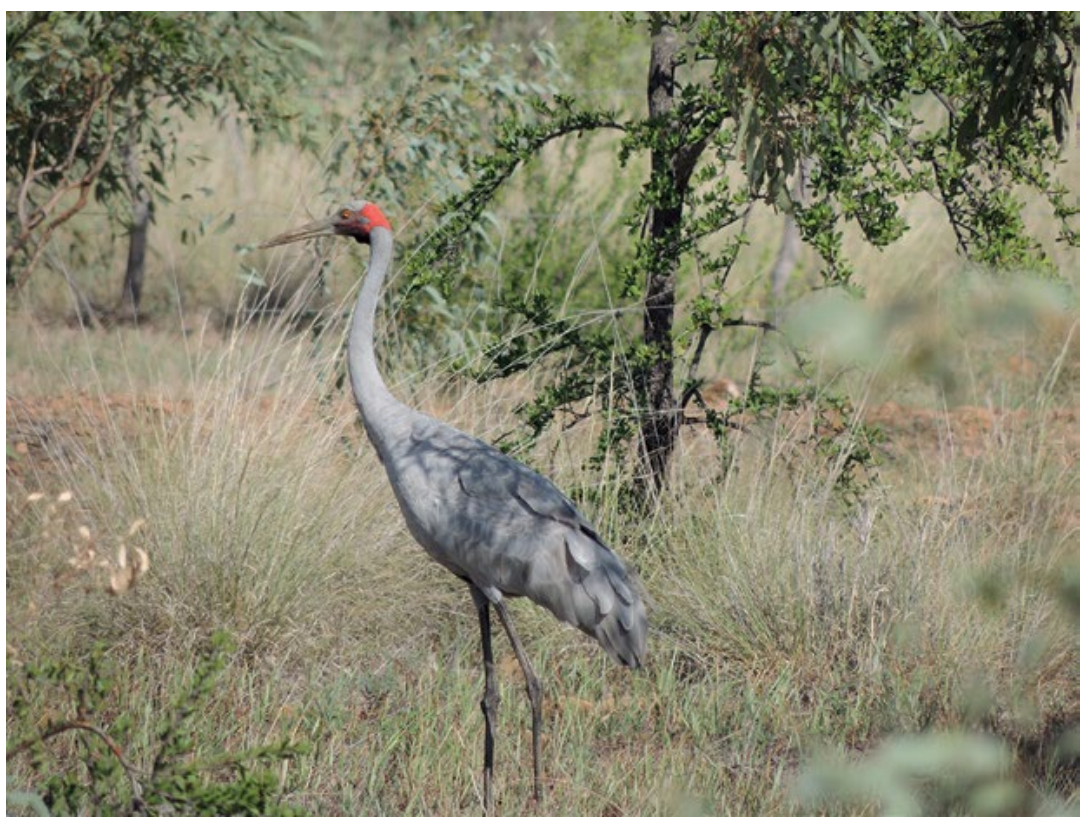

Figure 13.3: The brolga (Grus rubicunda) is one species that could benefit from environmental management in tropical savannas.

Source: Photo by Romy Greiner. 
To ensure sufficient uptake to be effective and efficient, agri-environment schemes need to be carefully tailored to the contextual conditions. Of course, an agri-environment scheme is principally there to address an environmental problem and is only fit for purpose if the conservation requirements effectively address this problem. However, agri-environment schemes must equally succeed in engaging with the diversity of businesses, preferences, and attitudes of the target audience. The environmental success of agri-environment schemes depends on voluntary participation and farmers' willingness to participate, given the contractual conditions.

The challenge for the design and administration of agri-environment schemes is how to achieve effectiveness and efficiency of a program, and also consider matters of equity and procedural justice. On the basis of the research outlined herein, the following principles require consideration:

- Contracts need to stipulate conservation actions that meet the requirements of the biodiversity targeted for conservation. If some production can co-exist with conservation, farmers are significantly more willing to participate.

- Giving farmers a suite of contract options to choose from helps to entice landholder participation by responding to diverse cost structures (opportunity costs, risk premiums and transaction costs), diverse preferences for contract attributes, and diverse motivations and attitudes.

- Care needs to be taken to ensure that program features do not crowd out voluntary conservation actions that farmers may already be providing. This is particularly problematic in places such as northern Australia, where many farmers attribute a high value to biodiversity and are strongly motivated by stewardship considerations.

- In situations where intrinsic motivation is low and/or attitudes towards agri-environment schemes are unfavourable, complementary strategies are required to create an improved psychological foundation for agri-environment scheme participation. Complementary strategies can include information and extension efforts to articulate the values of biodiversity and demonstrate how farming impacts biodiversity, and showcase the effects of conservation actions. Regulatory and statutory requirements on landholders, for example in the form of an environmental duty of care (Greiner 2014b), are relevant supporting mechanisms. 
- Allowing farmers to negotiate their land area contribution to an agri-environment scheme is important, particularly in an environment where individual operators are custodians of very large areas of land (the typical size of a pastoral station in northern Australia is around 2,500-10,000 $\mathrm{km}^{2}$ ). This gives rise to the scenario where a single farmer may control significant biodiversity assets on a portion of the property's area, so that engaging this single farmer in a conservation contract may be critical for safeguarding those biodiversity assets. The locality-specificity of biodiversity conservation combined with low number of potential services providers reduces opportunities for investors to implement agri-environment schemes in a competitive fashion (e.g. through environmental tenders). In such scenarios, negotiated approaches will be required with small numbers or single pastoralists who can achieve a desired conservation outcome. Successful negotiation will require a flexible approach to contract design.

- Biodiversity conservation on private land, funded by voluntary contractual arrangements, is an expensive way to do conservation, as the European experience shows (Batáry et al. 2015, p. 1014) and as the results of this research confirm. From the perspective of efficiency and permanency, inclusion of land into the formal conservation estate is preferable. However, agri-environment schemes can play a vital role of securing strategically important areas into a multi-tenure conservation system in the short- to medium-term.

\section{Acknowledgements}

This work was jointly funded by the National Environmental Research Program - Northern Australia Hub and Charles Darwin University. The author conducted the research at Charles Darwin University.

\section{References}

Ajzen, I. (1991) 'The theory of planned behaviour', Organizational Behavior and Human Decision Processes 50: 179-211.

Batáry, P., L.V. Dicks, D. Kleijn and W.J. Sutherland (2015) 'The role of agri-environment schemes in conservation and environmental management', Conservation Biology, 29: 1006-16. 
Broch, S.W. and S.E. Vedel (2012) 'Using choice experiments to investigate the policy relevance of heterogeneity in farmer agrienvironmental contract preferences', Environmental and Resource Economics 51: 561-81.

Burton, R.J.F. and G. Schwarz (2013) 'Result-oriented agri-environmental schemes in Europe and their potential for promoting behavioural change', Land Use Policy 30: 628-41.

Espinosa-Goded, M., J. Barreiro-Hurlé and E. Ruto (2010) 'What do farmers want from agri-environmental scheme design?: A choice experiment approach', Journal of Agricultural Economics 61: 259-73.

Garrod, G., E. Ruto, K. Willis and N. Powe (2012) 'Heterogeneity of preferences for the benefits of environmental stewardship: A latent-class approach', Ecological Economics 76: 104-11.

Greiner, R. (2014a) Survey of north Australian graziers and pastoralists with choice experiment regarding participation in contractual biodiversity conservation, dataset and questionnaire, Charles Darwin University. Available at: espace.cdu.edu.au/view/cdu:41684.

Greiner, R. (2014b) 'Environmental duty of care: From ethical principle towards a code of practice for the grazing industry in Queensland (Australia)', Journal of Agricultural and Environmental Ethics 27: $527-47$.

Greiner, R. (2015) 'Factors influencing farmers' participation in contractual biodiversity conservation: A choice experiment with northern Australian pastoralists', Australian Journal of Agricultural and Resource Economics 58: 1-28.

Greiner, R., M.C.J. Bliemer and J. Ballweg (2014) ‘Design considerations of a choice experiment to estimate likely participation by north Australian pastoralists in contractual on-farm biodiversity conservation', Journal of Choice Modelling 10: 34-45.

Greiner, R., I. Gordon and C. Cocklin (2009a) ‘Ecosystem services from tropical savannas: Economic opportunities through payments for environmental services', The Rangeland Journal 31: 51-9. 
Greiner, R. and D. Gregg (2011) 'Farmers' intrinsic motivations, barriers to the adoption of conservation practices and effectiveness of policy instruments: Empirical evidence from northern Australia', Land Use Policy 28: 257-65.

Greiner, R., L. Patterson and O. Miller (2009b) 'Motivations, risk perceptions and adoption of conservation practices by farmers', Agricultural Systems 99: 86-104.

Maybery, D., L. Crase and C. Gullifer (2005) 'Categorising farming values as economic, conservation and lifestyle', Journal of Economic Psychology 26: 59-72.

Pannell, D.J., G.R. Marshall, N. Barr, A. Curtis, F. Vanclay and R. Wilkinson (2006) 'Understanding and promoting adoption of conservation technologies by rural landholders', Australian Journal of Experimental Agriculture 46: 1407-24. 
This text is taken from Learning from agri-environment schemes in Australia: Investing in biodiversity and other ecosystem services on farms, edited by Dean Ansell, Fiona Gibson and David Salt, published 2016 by ANU Press, The Australian National University, Canberra, Australia. 